\title{
Anti-TNF immunotherapy reduces CD8+ T cell-mediated antimicrobial activity against Mycobacterium tuberculosis in humans
}

\author{
Heiko Bruns, ${ }^{1}$ Christoph Meinken, ${ }^{2}$ Philipp Schauenberg, ${ }^{3}$ Georg Härter, ${ }^{4}$ Peter Kern, ${ }^{4}$ \\ Robert L. Modlin, ${ }^{5}$ Christian Antoni, ${ }^{3}$ and Steffen Stenger ${ }^{1}$ \\ ${ }^{1}$ Institute for Medical Microbiology and Hygiene, University Hospital of Ulm, Ulm, Germany. ${ }^{2}$ Institute for Clinical Microbiology, Immunology and Hygiene, and \\ ${ }^{3}$ Department for Internal Medicine 3, University Erlangen-Nürnberg, Erlangen, Germany. ${ }^{4}$ Section of Infectious Diseases and Clinical Immunology, \\ University Hospital of Ulm, Ulm, Germany. ${ }^{5}$ Department of Medicine, Division of Dermatology, \\ UCLA David Geffen School of Medicine, Los Angeles, California, USA.
}

\begin{abstract}
The incidence of tuberculosis is increased during treatment of autoimmune diseases with anti-TNF antibodies. This is a significant clinical complication, but also provides a unique model to study immune mechanisms in human tuberculosis. Given the key role for cell-mediated immunity in host defense against Mycobacterium tuberculosis, we hypothesized that anti-TNF treatment impairs T cell-directed antimicrobial activity. Anti-TNF therapy reduced the expression in lymphocytes of perforin and granulysin, 2 components of the $T$ cell-mediated antimicrobial response to intracellular pathogens. Specifically, M. tuberculosis-reactive CD8 ${ }^{+} \mathrm{CCR}^{-}$ $\mathrm{CD}^{2} \mathrm{RA}^{+}$effector memory $\mathrm{T}$ cells $\left(\mathrm{T}_{\mathrm{EMRA}}\right.$ cells) expressed the highest levels of granulysin, lysed $\mathrm{M}$. tuberculosis, and infected macrophages and mediated an antimicrobial activity against intracellular M. tuberculosis. Furthermore, $T_{\text {EMRA }}$ cells expressed cell surface TNF and bound the anti-TNF therapeutic infliximab in vitro, making them susceptible to complement-mediated lysis. Immune therapy with anti-TNF was associated with reduced numbers of $\mathrm{CD8}^{+} \mathrm{T}_{\mathrm{EMRA}}$ cells and decreased antimicrobial activity against $M$. tuberculosis, which could be rescued by the addition of $\mathrm{CD8}^{+} \mathrm{T}_{\mathrm{EMRA}}$ cells. These results suggest that anti-TNF therapy triggers a reduction of $\mathrm{CD8}^{+} \mathrm{T}_{\mathrm{EMRA}}$ cells with antimicrobial activity against $M$. tuberculosis, providing insight into the mechanism whereby key effector $T$ cell subsets contribute to host defense against tuberculosis.
\end{abstract}

\section{Introduction}

The treatment of patients with monoclonal anti-TNF antibodies (infliximab) has led to a 4-fold increased incidence of tuberculosis (1), representing a major complication of anti-TNF therapy. Despite this potential side effect, infliximab treatment has revolutionized the treatment of severe forms of RA $(2,3)$, Crohn disease, psoriatic arthritis, and ankylosing spondylitis (AS) (4). The rationale for immune intervention with TNF-neutralizing agents resulted from 2 decades of basic research showing that TNF is a central component in the cascade of cytokines that trigger cell recruitment, inflammation, and ultimately tissue destruction (5). However, TNF is also a key molecule in host immunity to intracellular bacteria, most notably tuberculosis (6). Mice deficient in TNF production are highly susceptible to primary infection with Mycobacterium tuberculosis (7), and depletion of TNF by treatment with anti-TNF antibodies results in reactivation of latent disease (8-11). TNF fails to elicit antimycobacterial activity in human host cells in vitro (12-15), although in vivo, the critical role is illustrated by the reactivation of latent disease in anti-TNF-treated individuals $(16,17)$.

A key aspect of host defense against tuberculosis is the antigenspecific adaptive $\mathrm{T}$ cell response. Traditionally, the $\mathrm{T}$ cell-medi-

Authorship note: Heiko Bruns and Christoph Meinken contributed equally to this work.

Conflict of interest: The authors have declared that no conflict of interest exists.

Nonstandard abbreviations used: AS, ankylosing spondylitis; $\mathrm{T}_{\mathrm{CM}}$, central memory $\mathrm{T}$ (cell); $\mathrm{T}_{\mathrm{EM}}$, effector memory $\mathrm{T}$ (cell); $\mathrm{T}_{\mathrm{EMRA}}, \mathrm{CD} 45 \mathrm{RA}^{+}$effector memory $\mathrm{T}$ (cell); $\mathrm{TST}$, tuberculin skin test.

Citation for this article: J. Clin. Invest. 119:1167-1177 (2009). doi:10.1172/JCI38482. ated response against $M$. tuberculosis was believed to be dominated by IFN- $\gamma$-releasing $\mathrm{CD}^{+}{ }^{+} \mathrm{T}$ cells. However, it has become increasingly clear that cytotoxic $\mathrm{CD}^{+} \mathrm{T}$ cell subsets $(18-20)$ and $\mathrm{CD}^{+}$ $T$ cells contribute to protective immunity against $M$. tuberculosis (21). $\mathrm{CD}^{+} \mathrm{T}$ cells contribute to host defense by the release of Th1 cytokines and the coordinate interaction of chemotactic, lytic, and antimicrobial molecules, including the antimicrobial pathway mediated by perforin and granulysin $(22,23)$.

Granulysin is a member of the saposin-like family of lipidbinding proteins (24) that is expressed in intracellular granules of cytotoxic lymphocyte subsets, including NK cells (25), CD4 ${ }^{+}$ T cells $(19,26), \mathrm{CD}^{+} \mathrm{T}$ cells $(22,23,27)$, NKT cells $(28)$, and TCR $\gamma \delta$ T cells (29). The major functions are lysis of tumor cells (30), support of inflammation $(31,32)$, and killing of microbial pathogens $(22,25,33-36)$. Current knowledge of the relevance of the perforin/granulysin pathway of antimicrobial activity in vivo is limited because suitable animal models are not available, largely because there is no granulysin homolog in mice.

The use of anti-TNF monoclonal antibodies as immune therapy in patients with autoimmune disease is associated with an increased incidence of tuberculosis and provides what we believe to be a unique clinical model to search for immunological mechanisms that are critical for $M$. tuberculosis containment and that predispose to the reactivation of latent tuberculosis in humans. We therefore hypothesized that anti-TNF immune therapy alters a key $\mathrm{T}$ cell population required for host defense against tuberculosis in humans. The results presented here demonstrate that granulysinexpressing CD8 ${ }^{+} \mathrm{CCR}^{-}{ }^{-} \mathrm{CD} 45 \mathrm{RA}^{+}$effector memory $\mathrm{T}$ cells ( $\mathrm{T}_{\mathrm{EMRA}}$ cells) decreased during anti-TNF treatment. This subset had anti- 
Table 1

Characteristics of patients included in the study

\begin{tabular}{|c|c|c|c|c|c|c|}
\hline $\begin{array}{l}\text { Patient } \\
\text { no. }\end{array}$ & Disease & $\begin{array}{c}\text { Disease } \\
\text { duration (yr) }\end{array}$ & $\begin{array}{l}\text { Age } \\
\text { (yr) }\end{array}$ & Sex & $\begin{array}{c}\text { Erythrocyte } \\
\text { sedimentation }^{A}\end{array}$ & TST $^{B}$ \\
\hline 1 & RA & 6 & 58 & M & $47 / 24$ & Negative \\
\hline 2 & $\mathrm{RA}$ & 10 & 48 & $\mathrm{~F}$ & $65 / 40$ & Negative \\
\hline 3 & RA & 7 & 34 & $\mathrm{~F}$ & $6 / 5$ & Negative \\
\hline 4 & RA & 6 & 61 & M & $51 / 75$ & Negative \\
\hline 5 & $\mathrm{RA}$ & 22 & 60 & $\mathrm{~F}$ & $29 / 15$ & Negative \\
\hline 6 & $\mathrm{RA}$ & 5 & 28 & $M$ & $19 / 17$ & Negative \\
\hline 7 & RA & 28 & 47 & M & $42 / 30$ & Negative \\
\hline 8 & $\mathrm{RA}$ & 12 & 64 & $M$ & $41 / 12$ & Negative \\
\hline 9 & AS & 6 & 33 & $M$ & $18 / 3$ & Negative \\
\hline 10 & AS & 3 & 37 & $\mathrm{~F}$ & $8 / 2$ & Negative \\
\hline 11 & AS & 1 & 30 & $M$ & $1 / 3$ & Negative \\
\hline 12 & AS & 2 & 31 & $M$ & $67 / 2$ & Negative \\
\hline 13 & AS & 14 & 36 & $M$ & $20 / 3$ & Negative \\
\hline 14 & AS & 8 & 43 & $\mathrm{~F}$ & $32 / 10$ & $15 \mathrm{~mm}$ \\
\hline 15 & AS & 9 & 29 & $M$ & $39 / 7$ & $11 \mathrm{~mm}$ \\
\hline 16 & AS & 11 & 52 & M & $16 / 5$ & $12 \mathrm{~mm}$ \\
\hline 17 & RA & 12 & 22 & $\mathrm{~F}$ & $25 / 17$ & $18 \mathrm{~mm}$ \\
\hline
\end{tabular}

$\mathrm{M}$, male; F, female. ${ }^{A}$ Values (in $\mathrm{mm}$ ) show sedimentation at 1 hour/2 hours. BPositive values denote diameter of induration.

microbial activity and may be critical for maintaining latency in patients infected with M. tuberculosis.

\section{Results}

We hypothesized that anti-TNF immune therapy leads to an alteration of the adaptive $T$ cell response against $M$. tuberculosis, thereby triggering reactivation of latent tuberculosis. Given the key roles of perforin and granulysin in a T cell-mediated antimicrobial pathway, we initially studied expression of these proteins in patients receiving anti-TNF therapy. Patients with active RA $(n=9)$ or AS $(n=8$; Table 1$)$ that were scheduled to receive therapy with antiTNF antibodies (infliximab) were recruited, and the expression of perforin and granulysin in lymphocytes was compared before the first infliximab infusion and before the second infusion 2 weeks later by intracellular flow cytometry (Figure 1). During the course of immunotherapy, perforin and granulysin expression dropped significantly in all donors tested $(P<0.001)$, indicating that the perforin/granulysin axis of antimicrobial activity was disturbed by anti-TNF treatment. The levels of perforin and granulysin expression in the peripheral blood of patients with autoimmune diseases was not significantly different compared with healthy donors (perforin, $19 \% \pm 17 \%$ in 36 healthy donors; granulysin, $23 \% \pm 21 \%$ in 39 healthy donors).

Because TNF had no direct effect on the gene or protein expression of granulysin in PBMCs (data not shown), we reasoned that changes in lymphocyte subsets were responsible for the reduction of perforin ${ }^{+}$and/or granulysin ${ }^{+}$lymphocytes. Because granuly-

\section{Figure 1}

Decreased expression of lytic and antimicrobial effector molecules in patients treated with infliximab. PBMCs from patients with active RA or AS were stained for perforin $(n=7)$ or granulysin $(n=17)$ before and 2 weeks after beginning therapy. The percentage of granulysin ${ }^{+}$and perforin+ lymphocytes was determined by flow cytometry. Shown are results from all individual donors tested. $\sin$ is expressed in numerous lymphocyte subgroups (19, $22,23,25-29)$, we initially sought to identify subsets with prominent granulysin expression in the peripheral blood. We labeled PBMCs from 27 healthy donors with granulysin and markers for T cells (CD4 and CD8), NK cells (CD56), and B cells (CD19). The number of granulysin ${ }^{+}$cells ranged from $11 \%$ to $46 \%$ and was $23 \%$ on average (data not shown). The majority of granulysin ${ }^{+}$cells were NK cells $(51 \% \pm 27 \%)$ or $\mathrm{CD}^{+} \mathrm{T}$ lymphocytes $(28 \% \pm 13 \%$; Figure 2$)$.

$\mathrm{CD}^{+} \mathrm{T}$ cells can be subdivided into functional subsets, including naive $T$ cells, memory $T$ cells, and at least 2 types of effector T cells (37-39). These subsets were defined according to the expression of CCR7 and CD45RA: naive cells are CCR7 ${ }^{+} \mathrm{CD} 45 \mathrm{RA}^{+}$, central memory $\mathrm{T}\left(\mathrm{T}_{\mathrm{CM}}\right)$ cells are $\mathrm{CCR}^{+} \mathrm{CD}^{4} \mathrm{RA}^{-}$, effector memory $\mathrm{T}\left(\mathrm{T}_{\mathrm{EM}}\right)$ cells are CCR7$\mathrm{CD} 4 \mathrm{RA}^{-}$, and $\mathrm{T}_{\mathrm{EMRA}}$ cells are CCR7-CD45RA ${ }^{+}$. To identify $\mathrm{CD}^{+} \mathrm{T}$ cell subsets with pronounced expression of granulysin, we quadruple-labeled lymphocytes of healthy donors with antibodies to granulysin, CD8, CD45RA, and CCR7 (Figure 3 ). The majority of $\mathrm{CD}^{+}{ }^{+}$granulysin ${ }^{+}$cells were $\mathrm{T}_{\mathrm{EM}}$ cells $(91 \% \pm 4 \%)$, and approximately half were $\mathrm{T}_{\mathrm{EMRA}}$ cells. $\mathrm{CD}^{+}$NKT or NK cells expressed no marked amounts of intracellular granulysin (Figure 3A). Similarly, perforin was predominantly expressed in $\mathrm{T}_{\mathrm{EM}}$ cells $(96 \% \pm 6 \%)$, with a clear preference for $\mathrm{T}_{\text {EMRA }}$ cells $(73 \% \pm 18 \%$; Figure $3 \mathrm{~B})$. This expression pattern was very similar to that of granulysin and further supported the functional link between lytic and antimicrobial effector molecules in this subset.

To evaluate whether $\mathrm{CD}^{+} \mathrm{T}_{\mathrm{EM}}$ or $\mathrm{T}_{\mathrm{EMRA}}$ cells mediate antimycobacterial activity, we first measured cytotoxic activity of purified $\mathrm{T}_{\mathrm{EM}}$ cells, $\mathrm{T}_{\mathrm{EMRA}}$ cells, $\mathrm{T}_{\mathrm{CM}}$ cells, or PBMCs against autologous monocytes infected with virulent $M$. tuberculosis. $T_{\mathrm{EM}}$ cells, most notably $\mathrm{T}_{\text {EMRA }}$ cells, were highly efficient in lysing infected macrophages (Figure 4A). Significant lysis was detected at an effector/target ratio of $3: 1(12 \% \pm 2 \%)$ and reached $36 \% \pm 3 \%$ at an effector/target ratio of 30:1. Total PBMCs and $\mathrm{T}_{\mathrm{EM}}$ cells induced less than $50 \%$ lysis compared with $\mathrm{T}_{\text {EMRA }}$ cells at effector/target ratios of 10:1 and 30:1. Lytic activity was antigen specific, because lysis of uninfected monocytes was below $7 \%$ in all samples (data not shown). Because perforin-mediated pore formation facilitates granulysin-mediated antimicrobial activity, we next cocul-
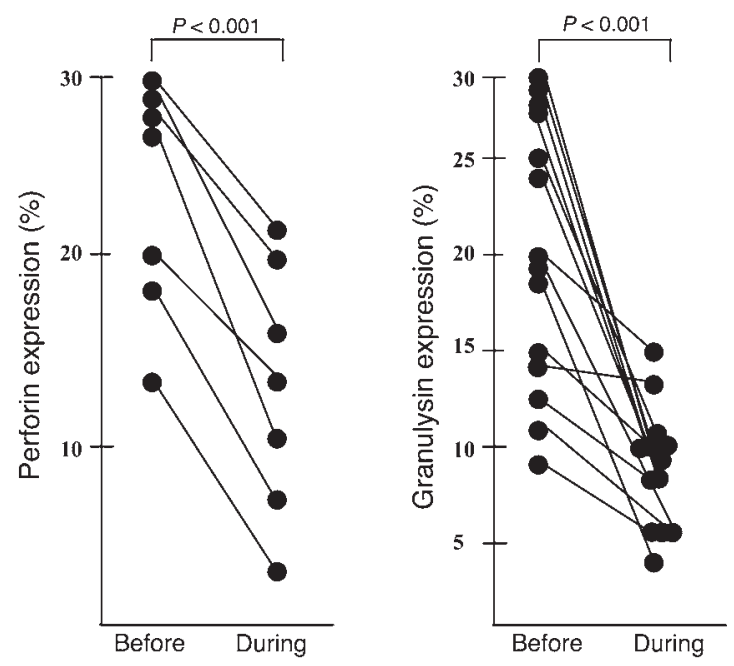


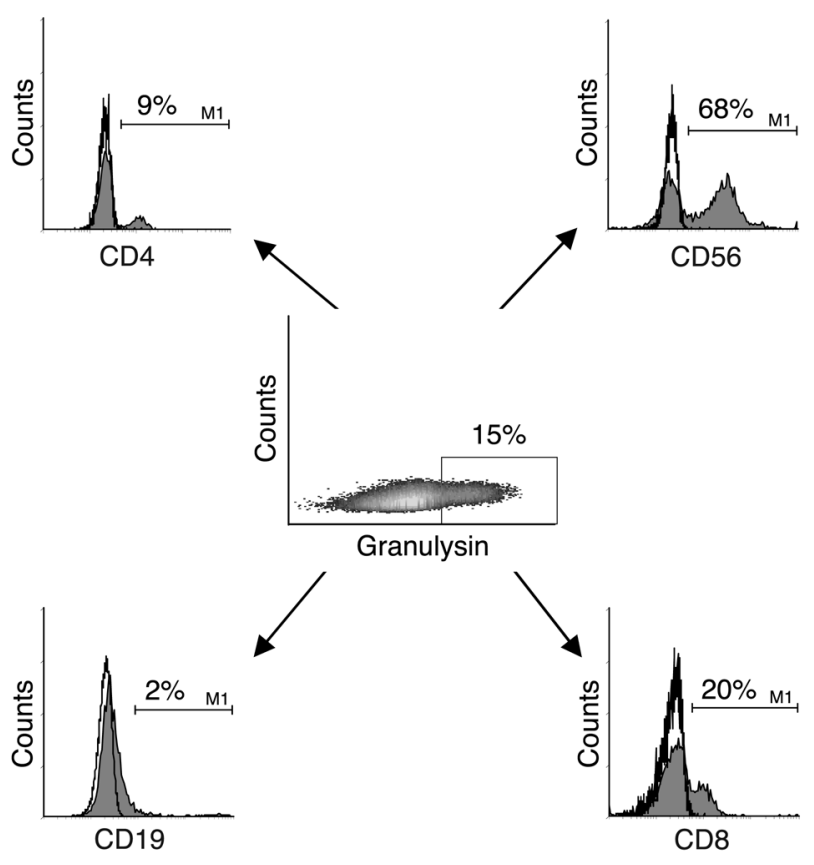

tured purified $\mathrm{T}_{\mathrm{EMRA}}$ cells, $\mathrm{T}_{\mathrm{EM}}$ cells, $\mathrm{T}_{\mathrm{CM}}$ cells, and PBMCs with M. tuberculosis-infected monocytes and determined mycobacterial survival after 36 hours. The pattern of antimicrobial activity was very similar to the lytic activity (Figure 4B). Reduced bacterial

\section{Figure 2}

The majority of granulysin ${ }^{+}$cells in the peripheral blood are cytotoxic lymphocytes. PBMCs from healthy donors were stained with PE-Cy5-5-conjugated anti-CD4, PE-conjugated anti-CD56, allophycocyanin-conjugated anti-CD19, PerCP-conjugated anti-CD8 (filled histograms), or appropriate isotype controls (open histograms). All samples were then stained for granulysin using FITC-conjugated donkey anti-rabbit as a secondary antibody. Granulysin+ cells were gated according to the isotype (control rabbit serum, not shown) and analyzed for the expression of cell surface markers. The percentages of $\mathrm{CD}^{+}, \mathrm{CD}^{2} 6^{+}, \mathrm{CD} 19^{+}$, and $\mathrm{CD} 8^{+}$cells within the granulysin gate are indicated. Shown is a typical result of 27 donors.

growth was most remarkable for $\mathrm{T}_{\mathrm{EMRA}}$ cells $(47 \% \pm 6 \%)$ compared with $\mathrm{T}_{\mathrm{EM}}$ cells $(28 \% \pm 3 \%)$, with little or no effect for $\mathrm{T}_{\mathrm{CM}}$ cells or PBMCs. Antimicrobial activity was antigen specific, because $\mathrm{T}$ cells purified from donors negative for tuberculin skin test (TST- donors) had no effect on mycobacterial survival (Figure $4 \mathrm{~B})$. Taken together, these results show that $\mathrm{CD}^{+} \mathrm{T}_{\mathrm{EMRA}}$ cells account for the majority of antimycobacterial effector cells in the peripheral blood.

To determine whether immunotherapy with anti-TNF antibodies modifies the frequency of $\mathrm{CD}^{+} \mathrm{T}_{\text {EMRA }}$ cells in vivo, we monitored the numbers of this antimicrobial lymphocyte subset in 7 patients during treatment. While the percentage of $\mathrm{CD}^{+} \mathrm{T}$ cells, $\mathrm{T}_{\mathrm{EM}}$ cells, and $\mathrm{T}_{\mathrm{CM}}$ cells did not change during the first 2 weeks of therapy, the frequency of $\mathrm{T}_{\mathrm{EMRA}}$ cells decreased in all donors during infliximab treatment by $29 \%$ on average (range, $15 \%-55 \%$; Figure $5 \mathrm{~A}$ and
A

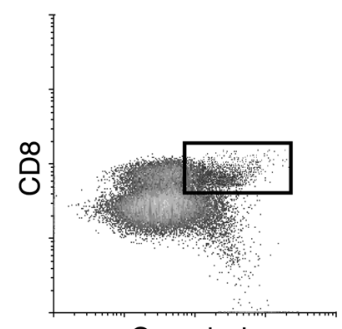

Granulysin

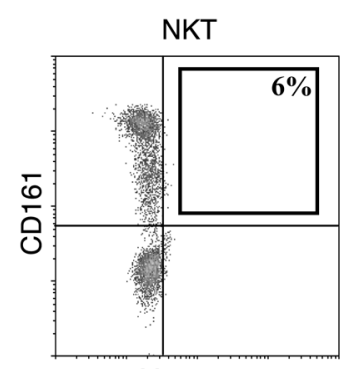

$\mathrm{V} \alpha 24$

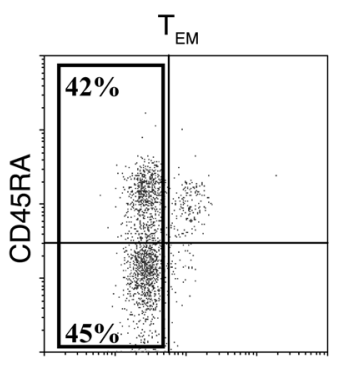

CCR7

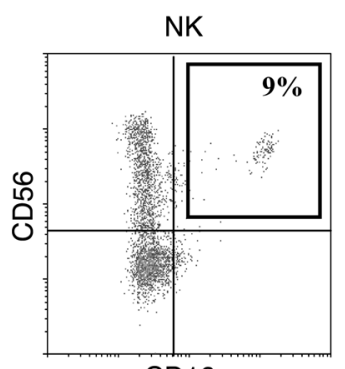

B

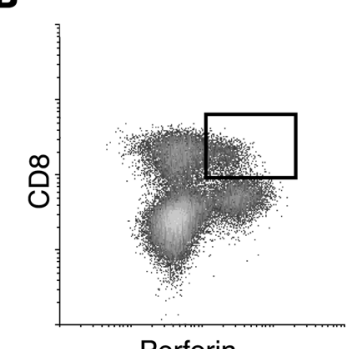

Perforin

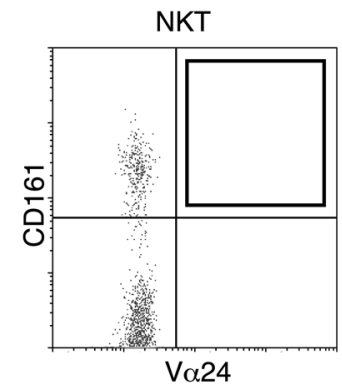

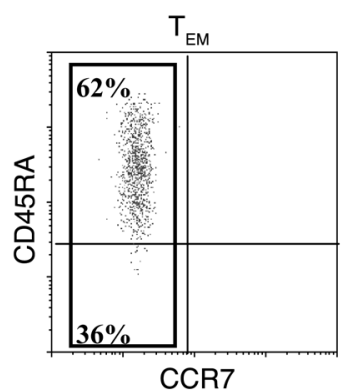

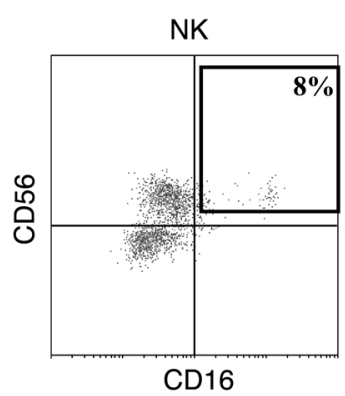

Figure 3

The majority of $\mathrm{CD}^{+}$and granulysin+ or perforin+ $\mathrm{T}$ cells are effector cells. PBMCs from healthy donors were stained with PerCP- or allophycocyanin-conjugated anti-CD8 and anti-granulysin (detected with donkey anti-rabbit biotin and streptavidin) or PE-conjugated perforin. Additional labeling was performed using allophycocyanin-conjugated anti-CD45RA and FITC-conjugated anti-CCR7 to detect $\mathrm{T}_{\mathrm{EM}}$ cells, PE-conjugated anti-CD161 and FITC-conjugated anti-V $\alpha 24$ to detect NKT cells, and PE-conjugated CD56 and FITC-conjugated anti-CD16 to detect NK cells. Samples with appropriate isotypes were included in all experiments. (A) CD8 $8^{+}$granulysin ${ }^{+}$cells were gated, and the expression of additional markers within this gate was determined. Numbers denote the percentage of positive effector cells, NKT cells, or NK cells within the population of CD8 ${ }^{+}$granulysin+ cells. For each sample, $1 \times 10^{6}$ cells were acquired. Shown is a typical result of 8 donors. (B) CD8 ${ }^{+}$perforin ${ }^{+}$cells were gated, and the expression of additional markers within this gate was determined. Numbers denote the percentage of positive effector cells, NKT cells, or NK cells within the population of CD8 ${ }^{+}$perforin ${ }^{+}$cells. For each sample, $1 \times 10^{6}$ cells were acquired. Shown is a typical result of 4 donors. 
A

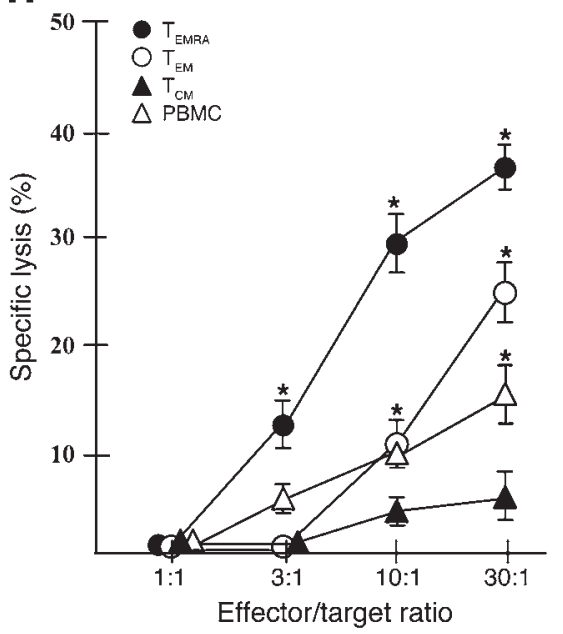

B

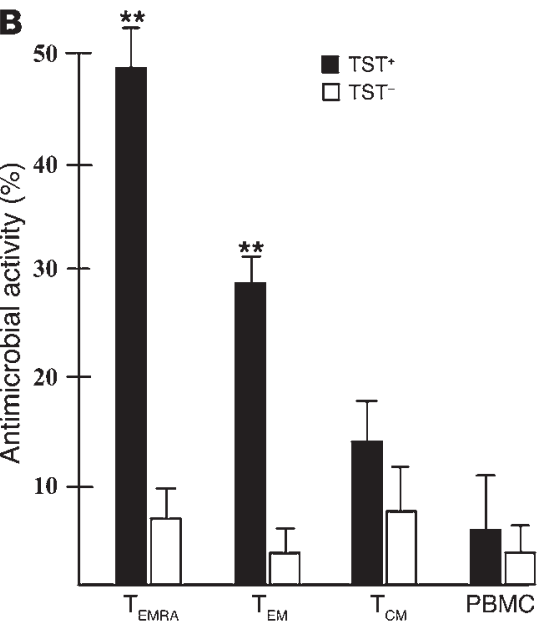

\section{Figure 4}

CD8 ${ }^{+} T_{\text {EMRA }}$ cells lyse $M$. tuberculosis-infected monocytes and reduce mycobacterial growth. CD8 ${ }^{+}$PBMCs were labeled with allophycocyaninconjugated anti-CD45RA and FITC-conjugated anti-CCR7 and sorted into $T_{E M R A}, T_{E M}$, and $T_{C M}$ cell subpopulations. (A) Purified T cells were added as effector cells in a ${ }^{51} \mathrm{Cr}$ release assay using autologous $M$. tuberculosis-infected (MOI 5) or uninfected monocytes as target cells. Supernatants were harvested after 4 hours, and ${ }^{51} \mathrm{Cr}$ release was determined. Shown is mean $\pm \mathrm{SEM}$ specific lysis of $M$. tuberculosis-infected monocytes of 4 independent experiments using different TST ${ }^{+}$donors. ${ }^{*} P<0.05$, infected versus uninfected monocytes. Lysis of uninfected monocytes was generally below $7 \%$. (B) T cell subsets were purified as described above and incubated with infected autologous monocytes $\left(5 \times 10^{4}\right.$ monocytes, $5 \times 10^{5} \mathrm{~T}$ cells/well). After 36 hours, cells were lysed and plated in 10-fold dilutions on $7 \mathrm{H} 9$ agar plates. All samples were set up in duplicate. Shown is mean \pm SEM reduction in the number of viable $M$. tuberculosis cells in monocytes cultured in the presence of T cells compared with monocytes cultured in the absence of T cells. The experiment was performed with 4 each of TST- and TST ${ }^{+}$donors. ${ }^{* \star} P<0.01$ versus TST-.

data not shown). The total lymphocyte counts, as determined by automated counting (range, 5,212-8,691 $\mu \mathrm{l}$ ), and the percentage of $\mathrm{CD}^{+} \mathrm{T}$ cells (Figure $5 \mathrm{~A}$ ) remained stable in individual patients during therapy. Accordingly, the relative decrease in the percentage of $\mathrm{T}_{\text {EMRA }}$ cells was reflected in a decrease in the absolute number of $\mathrm{T}_{\text {EMRA }}$ cells (range, 521-894 cells/ $\mu \mathrm{l}$ before therapy, 364-622 cells/ $\mu \mathrm{l}$ during therapy) in all 7 patients. An increase in the percentage of naive $T$ cells compensated for the reduced frequency of $\mathrm{T}_{\mathrm{EMRA}}$ cells (data not shown).

The number of $\mathrm{T}_{\text {EMRA }}$ cells returned to pretherapeutic levels after 3 months of therapy in all 7 donors and was stable at 1 year in the 5 donors that were available for follow-up (Figure 5B). Interest-
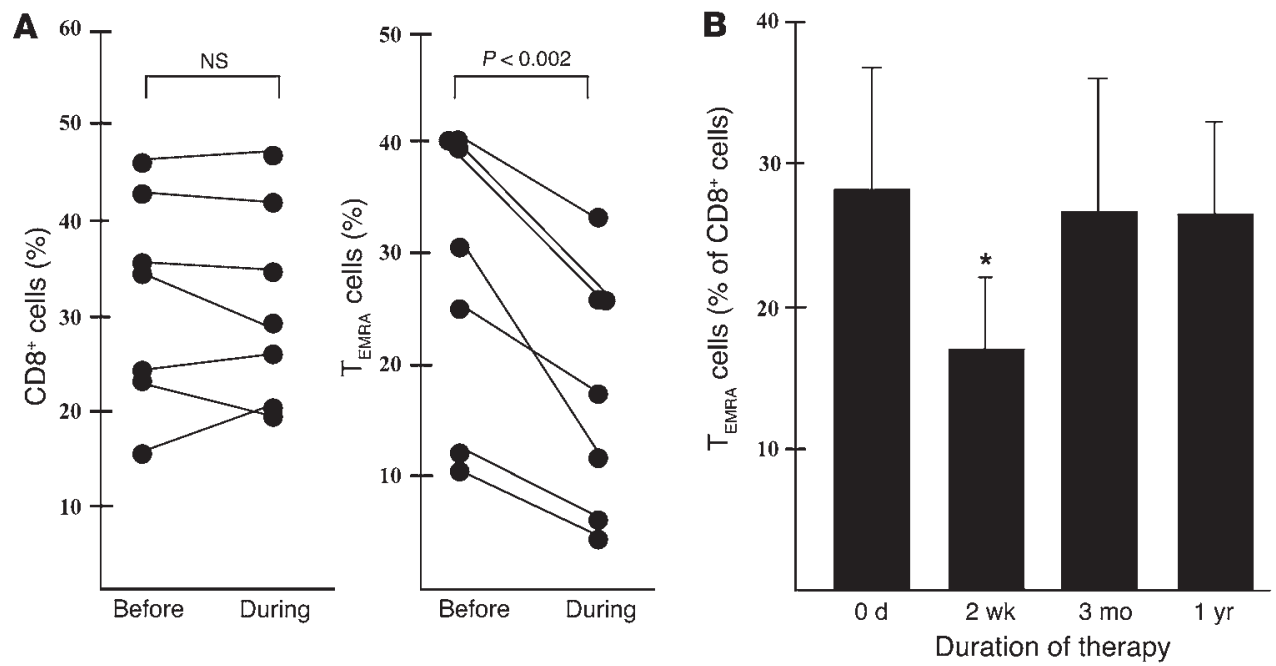

Figure 5

Decreased frequency of $T_{\text {EMRA }}$ cells in patients treated with infliximab. PBMCs from patients with RA or AS were stained for CD8 (PE conjugated), CD45 (allophycocyanin conjugated), and CCR7 (FITC conjugated) before, 2 weeks, 3 months $(n=7)$, and 1 year $(n=5)$ after the beginning of infliximab therapy. (A) The percentage of all CD8 ${ }^{+} \mathrm{T}$ cells within the lymphocyte gate and the percentage of $\mathrm{T}_{\text {EMRA }}$ cells within the CD8 gate were determined by flow cytometry. Shown is the percentage of CD8 ${ }^{+}$cells and TEMRA cells $(n=7)$ of all donors tested. (B) Mean number of TEMRA cells within $\mathrm{CD}^{+} \mathrm{T}$ cells of the same patients before and during infliximab therapy. ${ }^{*} P<0.05$ versus pretreatment value. 
A

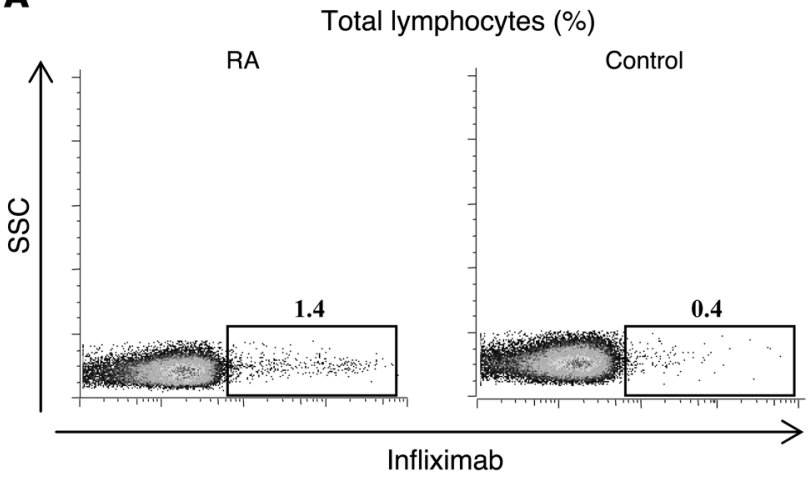

C

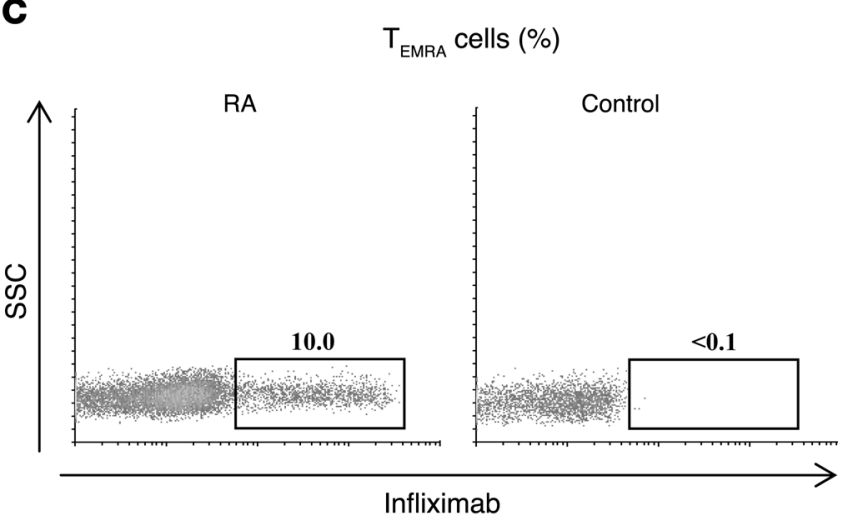

ingly, the majority of tuberculosis cases occur during the first 3 months of anti-TNF therapy (40), within the time period of reduced $\mathrm{T}_{\text {EMRA }}$ cell levels.

To investigate the mechanism by which anti-TNF immunotherapy resulted in a decrease of $C D 8^{+} T_{\text {EMRA }}$ cells, we explored whether freshly isolated PBMCs from patients with active RA express membrane TNF on the cell surface. The expression of membrane TNF, as measured by labeling with biotinylated infliximab, was higher in lymphocytes of 4 RA patients (mean, 2.1\%) than in those of 4 healthy controls (mean, $0.3 \%$; Figure 6, A and B). Further subset analysis demonstrated that $8.3 \% \pm 3.6 \%$ of $\mathrm{CD}^{+} \mathrm{T}_{\text {EMRA }}$ cells expressed infliximab, with the level undetectable in healthy controls (Figure 6, C and D), indicating an enrichment of infliximab ${ }^{+}$ cells within the $\mathrm{CD}^{+} \mathrm{T}_{\text {EMRA }}$ cell subset in RA patients. A considerable proportion of $\mathrm{T}$ cells expressing membrane TNF was CD8$(63 \% \pm 17 \%$; Table 2$)$. Most likely, these cells are $\mathrm{CD} 4^{+}$lymphocytes that play a major role in the pathogenesis of RA. Within the CD8 ${ }^{+}$ $T$ lymphocytes, $T_{\text {EMRA }}$ cells were by far the most prominent subset expressing membrane TNF ( $69 \% \pm 10 \%$, Table 2$)$, implicating their central role in anti-TNF-triggered immune modulation.

Based on these observations, we reasoned that exogenously added complement would be activated to attack anti-TNF-coated $\mathrm{T}_{\mathrm{EMRA}}$ cells. Freshly isolated PBMCs from patients with active RA were cultured with infliximab or a control antibody before addition of rabbit complement. The frequency of $\mathrm{T}_{\mathrm{EMRA}}$ cells decreased

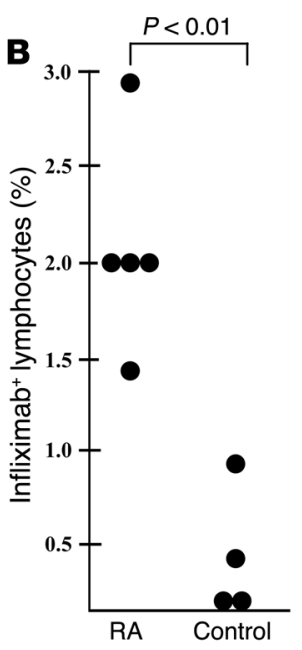

\section{Figure 6}

PBMCs of RA patients express membrane TNF. (A and B) PBMCs from patients with active RA $(n=5)$ or healthy controls $(n=4)$ were stained with biotinylated infliximab and allophycocyanin-conjugated streptavidin. Cells were acquired $\left(1 \times 10^{6}\right)$ and analyzed by flow cytometry. (A) Percentage of infliximab+ lymphocytes of 1 representative patient (left panel) and healthy donor (right panel). (B) Individual results from all donors tested. (C and D) PBMCs from patients with active RA $(n=4)$ or healthy controls $(n=4)$ were stained with biotinylated infliximab, PerCP-conjugated streptavidin, PE-conjugated anti-CD8, allophycocyaninconjugated anti-CD45RA, and FITC-conjugated anti-CCR7. CD8 ${ }^{+} T_{\text {EMRA }}$ cells were gated, and the percentage of infliximab+ cells was determined. For each sample,

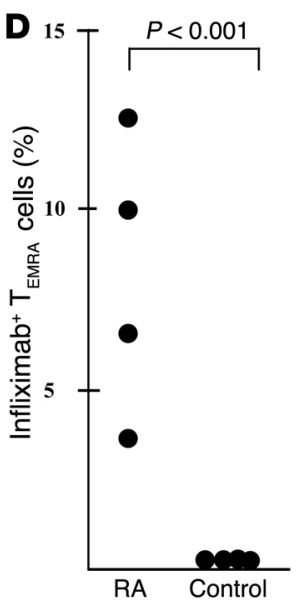
$5 \times 10^{6}$ cells were acquired. (C) Percentage of CD8+infliximab ${ }^{+} T_{\text {EMRA }}$ cells of 1 representative RA patient and healthy donor. (D) Individual results from all donors tested. in the PBMCs from all 4 patients treated with infliximab compared with control antibody-treated PBMCs (Figure 7). The percentage of infliximab ${ }^{+} \mathrm{T}_{\text {EMRA }}$ cells $(8.3 \% \pm 3.6 \%$, Figure $6 \mathrm{~B})$ was similar to the average decrease in $\mathrm{CD}^{+} \mathrm{T}_{\mathrm{EMRA}}$ cells by complement treatment in vitro $(6.8 \% \pm 2.6 \%$, Figure 7$)$. Taken together, these observations suggest that antimicrobial CD8 ${ }^{+} \mathrm{T}_{\text {EMRA }}$ cells are a preferred target for complement-mediated lysis in infliximab treated patients.

To evaluate whether the reduction in $\mathrm{T}_{\mathrm{EMRA}}$ cells is reflected in the ability to kill M. tuberculosis, we measured antimicrobial activity of

Table 2

Characterization of membrane TNF-expressing CD8 ${ }^{+} \mathrm{T}$ cells in RA patients

\begin{tabular}{lccccc} 
Patient & Total & \multicolumn{4}{c}{ Subset (\% of total) } \\
no. & CD8 $^{+}$ & Naive & $\mathbf{T}_{\text {CM }}$ & $\mathbf{T}_{\text {EM }}$ & T EMRA \\
1 & $31 \%$ & $9 \%$ & $23 \%$ & $4 \%$ & $64 \%$ \\
2 & $24 \%$ & $18 \%$ & $1 \%$ & $1 \%$ & $80 \%$ \\
3 & $57 \%$ & $8 \%$ & $23 \%$ & $8 \%$ & $61 \%$
\end{tabular}

PBMCs from patients with active RA were labeled for membrane TNF with infliximab (detected with PE-conjugated streptavidin), CD8, CD45RA, and CCR7. Shown are the percentage of total CD8 ${ }^{+} \mathrm{T}$ cells, based on gating of infliximab ${ }^{+}$cells, and the percent distribution of subsets within all CD8+infliximab+ $\mathrm{T}$ cells. 
A
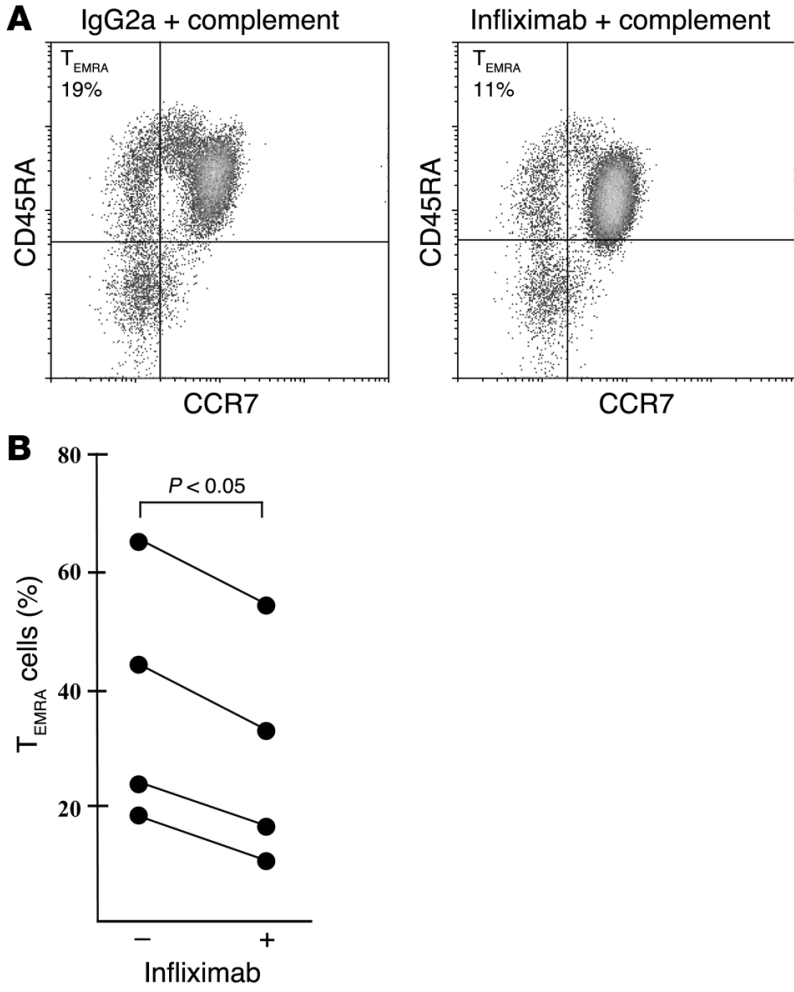

PBMCs in patients before and during anti-TNF therapy. Monocytes were isolated from $\mathrm{TST}^{+}$patients before and after the beginning of anti-TNF therapy and infected with virulent M. tuberculosis. Infected monocytes were incubated with autologous PBMCs, and the number of viable bacilli was determined after 24 and 96 hours of incubation. PBMCs from patients before therapy limited bacterial growth more efficiently than did PBMCs from patients during anti-TNF therapy at both time points (Figure 8A). This was not the result of differences in the uptake of bacilli by macrophages, because the initial load was similar in both groups, as determined by acid fast staining and plating of cell lysates before addition of PBMCs (data not shown). In contrast, there was no significant difference in antigenspecific IFN- $\gamma$ release between PBMCs obtained before and during therapy (Figure 8B). This result supports a model whereby lytic and antimicrobial $\mathrm{CD} 8^{+} \mathrm{T}_{\text {EMRA }}$ cells comprise a functionally unique subset that complements the cytokine-producing (e.g., IFN- $\gamma$ ) $\mathrm{CD}_{4}^{+}$ $T$ lymphocytes in order to eliminate M. tuberculosis.

To determine whether the relative deficiency of $\mathrm{CD} 8^{+} \mathrm{T}_{\text {EMRA }}$ cells was responsible for the reduced antimicrobial activity, PBMCs from TST ${ }^{+}$infliximabtreated patients were replenished with autologous, sorted $\mathrm{CD} 8^{+} \mathrm{T}_{\mathrm{EMRA}}$ cells, and mycobacterial growth was measured as described above. The initial bacterial load was $3.3 \pm 0.7 \times 10^{4} \mathrm{CFU}$, reflecting the facts that not all mycobacteria added to the culture were taken up and that not all macrophages take up mycobacteria $(21 \% \pm 12 \%$ of the macrophages were infected). The relative inability of PBMCs from patients during antiTNF therapy to limit the intracellular proliferation of

\section{Figure 8}

\section{Figure 7}

Complement reduces the frequency of infliximab ${ }^{+} \mathrm{T}_{\text {EMRA }}$ cells in RA patients. PBMCs from patients with active RA $(n=4)$ were incubated with infliximab or a control antibody. Rabbit complement was then added for 60 minutes, and the number of $T_{\text {EMRA }}$ cells was determined by labeling with CD8, CD45RA, and CCR7. (A) CD8 ${ }^{+}$lymphocytes were gated, and the representative graph shows the CD45RA and CCR7 labeling within the CD8 gate. (B) Individual results of all donors investigated.

virulent $M$. tuberculosis was rescued by $\mathrm{CD} 8^{+} \mathrm{T}_{\mathrm{EMRA}}$ cells (Figure 9). Although the percentage reduction of CFUs induced by $\mathrm{T}_{\text {EMRA }}$ cells was within an order of magnitude, $M$. tuberculosis infection in vivo is slow and protracted, and the time of in vitro assay was only 36 hours, so that a cumulative antimicrobial effect over time could have a profound effect on the number of bacilli during the course of infection. $T_{E M}$ cells were also effective, whereas $T_{C M}$ cells and $B$ cells had no effect on mycobacterial viability, reflecting the levels of granulysin expression (Figures 2 and 3).

In summary, these experiments identify $\mathrm{CD} 8^{+}$granulysin $^{+} \mathrm{T}_{\text {EMRA }}$ cells as antimicrobial effector cells in humans. Furthermore, these findings indicate that treatment of individuals with anti-TNF antibodies reduces the frequency of granulysin ${ }^{+} T_{\text {EMRA }}$ cells, providing a mechanism for the reactivation of latent tuberculosis infection.

\section{Discussion}

The reactivation of latent tuberculosis is a clinically significant complication of immunotherapy with anti-TNF antibodies, but it also provides an opportunity to investigate mechanisms of human host defense against mycobacterial infection in humans. Here we found that anti-TNF treatment induced a marked decrease
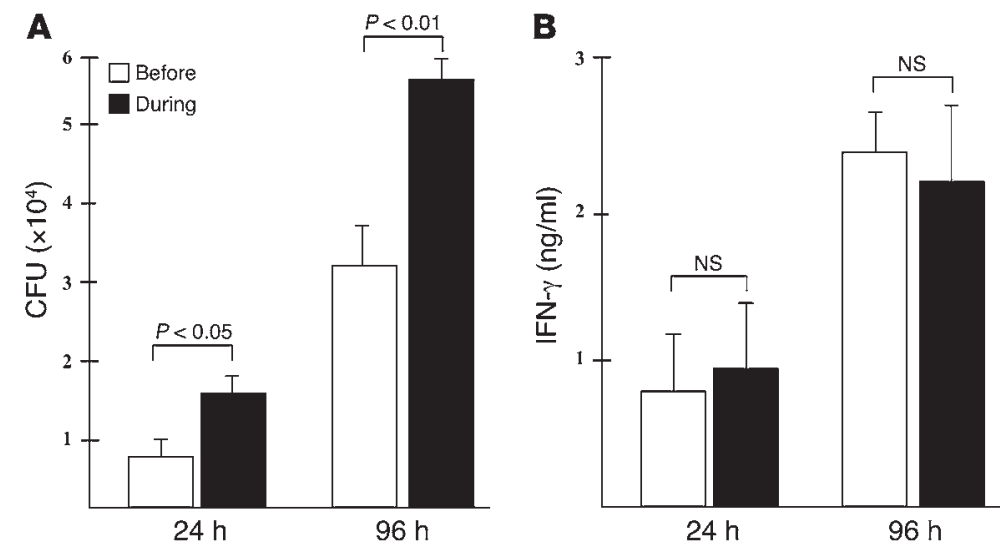

Infliximab therapy reduces the antimicrobial activity of PBMCs. PBMCs from TST ${ }^{+}$ patients $(n=4)$ with active RA or AS were collected before and 2 weeks after the onset of anti-TNF therapy and frozen in liquid nitrogen to allow for simultaneous measurement of antimycobacterial activity. Matched pairs were thawed, and adherent monocytes were infected with $M$. tuberculosis at MOI 5. Infected monocytes were detached and plated in 24-well plates as described in Methods. Autologous nonadherent cells $\left(1 \times 10^{6}\right)$ were added. $(\mathbf{A})$ The number of viable bacilli was determined by plating the cell lysates at 24 and 96 hours after infection. Shown is the mean \pm SEM number of CFUs of all 4 donors tested. (B) Supernatants from the same samples as in A were taken after 24 and 96 hours, and the concentration of IFN- $\gamma$ was measured by ELISA. Shown is the mean \pm SD concentration of IFN- $\gamma$ of all 4 donors. The IFN- $\gamma$ concentration in samples containing PBMCs, T cells, and uninfected macrophages was below the $30-\mathrm{pg} / \mathrm{ml}$ detection limit. 


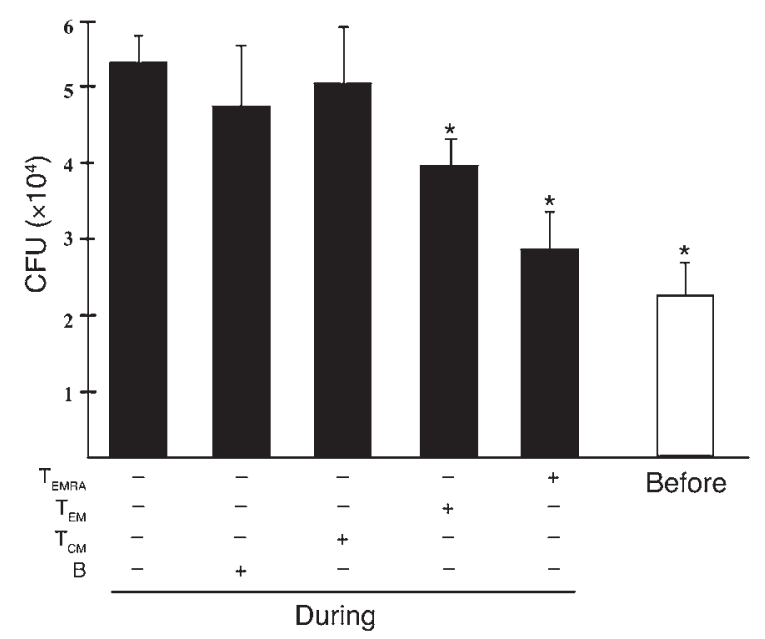

\section{Figure 9}

CD8 ${ }^{+} T_{\text {EMRA }}$ cells rescue antimycobacterial activity of PBMCs from patients during anti-TNF therapy. PBMCs from 3 consecutive patients with active RA or AS and TST+ were collected before and 2 weeks after beginning of anti-TNF therapy. Adherent cells were infected with virulent $M$. tuberculosis at MOI 5 for 3 hours, and extracellular bacteria were removed. Of the macrophages, $21 \% \pm 12 \%$ were infected (mean \pm SD of 3 donors), with each macrophage harboring 1-3 bacilli. Infected monocytes were detached and plated in 24-well plates $\left(5 \times 10^{4}\right)$. Concurrently, CD8 ${ }^{+} \mathrm{T}$ cells were purified from the nonadherent fraction and sorted by flow cytometry according to the CD45RA/CCR7 expression profile. CD20+ B cells were purified as a control population. Lymphocyte subsets were added to the infected monocytes $\left(2 \times 10^{5}\right)$ as indicated, and the number of viable bacilli was determined by plating cell lysates after 36 hours of infection. Lysates were plated in 5 -fold dilutions and in duplicates. The initial bacterial inoculum was $3.3 \pm 0.7 \times 10^{4}$. Shown is the mean \pm SEM of 1 experiment with each individual donor. ${ }^{*} P<0.05$ versus $C F U$ s cultured in the presence of PBMCs during therapy. of perforin and granulysin in lymphocytes, 2 components of direct $\mathrm{T}$ cell-mediated antimicrobial activity against intracellular M. tuberculosis. This reduction was caused by decreased frequency of the $\mathrm{T}_{\text {EMRA }}$ cell subset, which expressed granulysin and mediated a direct antimicrobial activity against $M$. tuberculosis in macrophages. $\mathrm{T}_{\text {EMRA }}$ cells expressed membrane TNF and bound infliximab, becoming susceptible to complement-mediated lysis. Together, these data identify the $\mathrm{T}_{\mathrm{EMRA}}$ cell subset as a requirement for optimal protection against tuberculosis in humans.

The experimental evidence implicating $\mathrm{CD}^{+} \mathrm{T}$ cells as pivotal in host defense in tuberculosis began with adoptive transfer and cell depletion studies in vivo in mouse models (41-43). Subsequent work showed that disruption of MHC class I antigen presentation to $\mathrm{CD}^{+} \mathrm{T}$ cells severely impaired host defense (44). Human M. tuberculosis-reactive $\mathrm{CD}^{+} \mathrm{T}$ cell lines and clones were found to lyse M. tuberculosis-infected macrophages in an antigen-specific manner and to restrict the growth of $M$. tuberculosis in macrophages $(45,46)$. Our own prior studies indicated that CD8 ${ }^{+}$ $\mathrm{T}$ cells contained one or more microbicidal effector molecules in their cytotoxic granules that are able to directly kill intracellular M. tuberculosis (47), including the antimicrobial protein granulysin (22). Here, linking T cell phenotypic and functional changes that occur during anti-TNF immunotherapy, we identified that a key $\mathrm{CD}^{+} \mathrm{T}$ cell subset, $\mathrm{T}_{\text {EMRA }}$ cells, is required for optimal host defense against tuberculosis in humans. Importantly, the decline in $T_{\text {EMRA }}$ cells during anti-TNF therapy was associated with a decrease in $\mathrm{T}$ cell-mediated antimicrobial activity. Furthermore, restoration of $\mathrm{T}_{\mathrm{EMRA}}$ cells in vitro also restored antimicrobial responses.

Importantly, $\mathrm{T}_{\text {EMRA }}$ cells strongly expressed the antimicrobial proteins granulysin and perforin, correlating with their direct antimicrobial activity against intracellular M. tuberculosis. Granulysin expression by lymphocytes decreased during anti-TNF therapy, as did T cell-mediated antimicrobial responses. Previously, $\mathrm{CD}^{+}{ }^{+}$granulysin ${ }^{+} \mathrm{T}$ cells were identified as mediating antimicrobial activity against $M$. tuberculosis-infected macrophages. Granulysin-containing cytoplasmic granules were required for this antimicrobial activity, because strontium treatment of $\mathrm{T}$ cells resulted in release of granulysin and reduced the antimicrobial response (22). Granulysin itself is an antimicrobial peptide with a broad range of antimicrobial activities against Gram-positive and Gram-negative organisms, including M. tuberculosis. The mechanism by which granulysin kills bacteria depends upon its positive charge and $\alpha$-helical structure facilitating binding to bacterial membranes and subsequent lysis of the pathogen (48). The tissue expression of granulysin correlated with the ability of the host to restrict infection in the mycobacterial disease leprosy (26). Plasma granulysin levels were found to correlate with host defense responses in human tuberculosis (49-51). Although granulysin is likely to contribute to host defense against microbial infection, it may also contribute to tissue injury by inducing necrosis of normal cells. For example, granulysin has previously been shown to induce keratinocyte death in Stevens-Johnson syndrome and toxic epidermal necrolysis (52), leading to skin blister formation. It remains to be determined whether granulysin contributes to tissue damage in human tuberculosis, such as the caseation necrosis that is a hallmark of the disease. Although our present findings as well as previous studies into the role of granulysin involve human donors and by nature are somewhat correlative, it is important to note that granulysin has no murine homolog, such that there are no adequate mouse models to study its role in vivo.

The demonstration that $\mathrm{CD}^{+} \mathrm{T}_{\mathrm{EMRA}}$ cells are required for optimal host defense against tuberculosis is consistent with, yet also extends, prior findings. $T_{\text {EMRA }}$ cells were previously recognized as the terminally differentiated stage of $\mathrm{T}_{\mathrm{EM}}$ cells that develop under the driving force of homeostatic mediators such as IL-15 $(39,53$, 54). This multistep maturation process involves conversion of $\mathrm{CCR}^{+}{ }^{+} \mathrm{CD} 45 \mathrm{RA}{ }^{+}$lymphocytes to CCR7-CD45RA ${ }^{+}$cells that express high levels of perforin, granzymes (37), and granulysin. There is a positive correlation between the frequency of $\mathrm{T}_{\mathrm{EMRA}}$ cells and efficient control of HIV-1 infection $(55,56)$, and a maturation defect of $\mathrm{T}_{\text {EMRA }}$ cells may represent an HIV-induced evasion mechanism (53). In Ebstein-Barr virus disease and cytomegalovirus-infected patients, $\mathrm{T}_{\text {EMRA }}$ cells are a major component of the antigen-specific effector cell pool in the blood and affected tissue and may account for the successful control of these viruses that regularly occurs in immunocompetent individuals $(53,57,58)$. A role for $\mathrm{CD}^{+} \mathrm{T}_{\mathrm{EMRA}}$ cells in tuberculosis was previously suggested by one elegant study measuring $M$. tuberculosis-specific responses by pentamer staining. In healthy, protected $\mathrm{TST}^{+}$children, the majority of antigenspecific $\mathrm{CD}^{+}$cells were $\mathrm{T}_{\mathrm{EMRA}}$ cells (59), whereas in patients that failed to control the tubercle bacilli, antigen-specific $\mathrm{CD}^{+}$cells were predominantly $\mathrm{T}_{\mathrm{CM}}$ cells (59). In another study, children with active tuberculosis had an increased frequency of $\mathrm{CD}^{+} \mathrm{CD} 45 \mathrm{R} 0^{-}$ CD28-CD27- effector cells, which are probably closely related to 
$\mathrm{T}_{\text {EMRA }}$ cells (60). Cells within this subset showed clonal expansion in severe disease, making a protective function counterintuitive. One previous report demonstrated that the frequency of $\mathrm{T}_{\mathrm{EMRA}}$ cells remains unchanged during the first 3 days of anti-TNF treatment (61). However, the observation period of the present study spanned the first weeks of therapy, which covers the time frame during which reactivation of tuberculosis occurs. The role of $\mathrm{T}_{\text {EMRA }}$ cells in host defense against tuberculosis warrants further investigation in other clinical settings, including in patients with tuberculous pleuritis, in which cell-mediated immunity is strong (62), and in cases of tuberculosis in the context of HIV infection, in which cell-mediated immunity is impaired (63). Additional studies will clarify whether $\mathrm{CD}^{+} \mathrm{T}_{\mathrm{EMRA}}$ cells, in addition to directly recognizing and eliminating $M$. tuberculosis-infected macrophages, also participate in the formation and maintenance of granulomas, as would be predicted by their unique and specific chemokine receptor expression pattern $(39,64)$.

Our present results provide a functional analysis of $\mathrm{T}_{\mathrm{EMRA}}$ cells in bacterial infection and favor a role for $\mathrm{T}_{\mathrm{EMRA}}$ cells in protective immunity in human tuberculosis. This insight also provides a mechanism for the reactivation of tuberculosis that occurs during anti-TNF immunotherapy. Among several infectious diseases that occur during infliximab therapy, the greatest threat comes from pathogens causing granulomatous infections, most notably M. tuberculosis (40). A likely explanation is that granuloma formation depends on coordinated cellular trafficking, which is altered by anti-TNF treatment $(16,65-67)$. The demonstration that $\mathrm{T}_{\text {EMRA }}$ cells express membrane TNF, bind anti-TNF antibodies, and subsequently become susceptible to complement-mediated lysis provides a cellular mechanism by which anti-TNF therapy influences adaptive immunity.

The expression of membrane TNF on PBMCs reflects the disease activity observed in our patients, as increased levels of TNF are a hallmark of autoimmune diseases and the rationale for the therapeutic intervention with TNF-neutralizing agents (5). The majority of TNF is present as a transmembrane protein, which needs to be cleaved by the metalloproteinase TNF- $\alpha$-converting enzyme (TACE) to be released into the extracellular space. While this process is very efficient in macrophages and dendritic cells, much of the TNF produced by $\mathrm{T}$ cells remains in the membrane form $(68,69)$. Therefore, the increased expression of membrane TNF on lymphocytes from patients with RA (Figure 6) reflects the inappropriate $\mathrm{T}$ cell activation that is responsible for the active disease diagnosed in our patients.

Patients treated with anti-TNF antibodies (e.g., infliximab) have a 5-fold higher risk for developing tuberculosis than do patients treated with soluble TNF receptors (e.g., etanercept; ref. 40). Also, the majority of tuberculosis reactivation occurs during the first 3 months of initiating infliximab therapy, whereas etanercept-mediated disease occurs much later (40). This different impact on host defense against $M$. tuberculosis is explained by previous findings on the interactions of TNF-neutralizing agents with membrane TNF. Etanercept binds poorly and with low avidity to transmembrane TNF $(70,71)$. Accordingly, etanercept is much less efficient than infliximab in triggering complement-dependent cytotoxicity $(70$, 71). The present data provide a rationale for determining whether $\mathrm{T}_{\text {EMRA }}$ cells are preserved during etanercept treatment.

Previous reports on anti-TNF-mediated effects on $\mathrm{T}$ cell responses to mycobacterial antigens showed a decreased expression of membrane TNF in stimulated $\mathrm{CD}^{+}{ }^{+} \mathrm{T}$ cells $(72)$, a variable effect on the number of IFN- $\gamma$-releasing cells $(72,73)$, and no changes in proliferation (72). The decrease of $\mathrm{T}_{\text {EMRA }}$ cells described in the present study clearly favors the establishment of an antiinflammatory environment. While this could be a disadvantage in protection against intracellular pathogens, the decrease of $\mathrm{T}_{\text {EMRA }}$ cells may contribute to the clinical success of anti-TNF therapy. For example, complement-mediated lysis of $\mathrm{T}_{\mathrm{EMRA}}$ cells may be the mechanism by which the number of perforin ${ }^{+}$cells and elevated granzyme levels in fluids and tissues of RA patients $(74,75)$ is normalized. Taken together, our own and others' studies $(61,76-83)$ strongly suggest that the correction of inappropriate $\mathrm{T}$ cell responses is a key mechanism by which anti-TNF therapy antagonizes the hyperinflammatory state that accounts for autoimmune diseases.

In summary, our findings demonstrated that anti-TNF therapy resulted in a significant reduction of $\mathrm{CD}^{+} \mathrm{T}_{\mathrm{EMRA}}$ cells, thereby disturbing an important component of protective immunity against intracellular bacteria. Therefore, $\mathrm{CD}^{+} \mathrm{T}_{\mathrm{EMRA}}$ cells should be considered as a target for manipulating immune responses: strengthening this compartment would be beneficial for infections, and counterregulation could improve autoimmune disease.

\section{Methods}

Cell culture reagents. Cells were cultured in complete medium, consisting of RPMI 1640 (Biochrom) supplemented with glutamine (2 mM; SigmaAldrich), $10 \mathrm{mM}$ HEPES, $13 \mathrm{mM} \mathrm{NaHCO} 3,100 \mathrm{~g} / \mathrm{ml}$ streptomycin, $60 \mathrm{~g} / \mathrm{ml}$ penicillin (all from Biochrom), and 5\% heat-inactivated human $\mathrm{AB}$ serum (Cambrex).

Antibodies and reagents. The following antibodies were used for flow cytometry: PE-Cy5.5-conjugated anti-CD4, FITC-conjugated anti-CD16, allophycocyanin-conjugated anti-CD19, allophycocyanin-conjugated anti-CD45RA, biotin-conjugated anti-mouse IgG1, and allophycocyanin/ PE-conjugated streptavidin (all from Caltag); PerCP/allophycocyaninconjugated anti-CD8, PE/allophycocyanin-conjugated anti-CD56, and PE-conjugated anti-perforin (all from BD Biosciences); FITC-conjugated anti-CCR7 (R\&D Systems); FITC-conjugated anti-V $\alpha 24$ (Immunotech); PE-conjugated anti-CD161 (Beckman Coulter); polyclonal granulysin rabbit serum (gift from A. Krensky, Stanford University, Stanford, California, USA); infliximab (Essex Pharma); etanercept (Wyeth Pharma); and Cy5-conjugated donkey anti-rabbit and biotin-conjugated goat anti-rabbit (Dianova). The following reagents were used: paraformaldehyde, saponin, sodium azide (Sigma-Aldrich), rabbit complement (BAG Healthcare), and EZ-Link NHS-Biotin Reagent (Pierce).

Flow cytometry. PBMCs were stained with cell surface markers for $30 \mathrm{~min}$ utes. Cells were then fixed with $4 \%$ paraformaldehyde $\left(10\right.$ minutes at $\left.4{ }^{\circ} \mathrm{C}\right)$ and incubated with permeabilization buffer $(0.5 \%$ saponin, $5 \%$ FCS, and $0.1 \%$ sodium acid) for 10 minutes. Polyclonal rabbit anti-human granulysin serum (1:5,000 dilution) or a control rabbit serum were added and incubated for 30 minutes at $4{ }^{\circ} \mathrm{C}$. After washing with permeabilization buffer, FITCor Cy5-conjugated donkey anti-rabbit (both 1:100 dilution) was added for 30 minutes. Cells were immediately analyzed by flow cytometry (FACScalibur; BD). At least $1 \times 10^{5}$ cells were acquired for each sample. Perforin staining was performed by incubating cells, fixed and permeabilized as described above, with $3 \mu \mathrm{l}$ PE-conjugated perforin or an isotype control antibody.

Growth of M. tuberculosis. M. tuberculosis virulent strain H37Rv was grown in suspension with constant gentle rotation in roller bottles containing Middlebrook 7H9 broth (BD Biosciences) supplemented with 1\% glycerol (Roth); 0.05\% Tween 80 (Sigma-Aldrich); and 10\% Middlebrook oleic acid, albumin, dextrose, and catalase enrichment (BD Biosciences). Aliquots from logarithmically growing cultures were frozen in PBS containing $10 \%$ glycerol, and representative vials were thawed and enumerated for viable 
CFU on Middlebrook 7H11 plates. Staining of bacterial suspensions with fluorochromic substrates differentiating between live and dead bacteria (BacLight; Invitrogen) revealed greater than $90 \%$ viability of the bacteria. Several precautions were taken to minimize clumping of mycobacteria: (a) culture conditions (rotation, Tween) were chosen to support the growth of single-cell suspensions; (b) before in vitro infection, $M$. tuberculosis bacilli were sonicated to disrupt small aggregates of bacteria; and (c) the MOI was selected such that there were only 1-3 bacilli per infected cell.

Infection of monocytes. Monocytes were infected with single-cell suspensions of M. tuberculosis at MOI 5 in complete medium without antibiotics and supplemented with $5 \%$ non-heat-inactivated human serum. After 3 hours of incubation at $37^{\circ} \mathrm{C}$, monocytes were washed 3 times to remove extracellular bacteria. Adherent cells were detached using 1 mM EDTA. The efficacy of infection was determined in each experiment by acid fast stain (auramin rhodamine) and was $25 \% \pm 13 \%$.

Cytotoxicity assay. Uninfected and infected monocytes were labeled with $100 \mu \mathrm{Ci}{ }^{51} \mathrm{Cr}$ (ICN Biomedicals) for 1 hour and plated in a 96-well V-bottom plate at a final concentration of 5,000 targets/100 $\mu$ l. CD8 ${ }^{+}$effector cells were purified from the nonadherent fraction by negative selection using magnetic beads per the manufacturer's recommendations (Miltenyi Biotec). Purified cells were then labeled with allophycocyanin-conjugated anti-CD45RA and FITC-conjugated anti-CCR7 and sorted using a cell sorter (MoFlow) as CCR7-CD45RA- ${ }^{-}\left(\mathrm{T}_{\mathrm{EM}}\right), \mathrm{CCR}^{+}{ }^{+} \mathrm{CD} 45 \mathrm{RA}^{-}\left(\mathrm{T}_{\mathrm{CM}}\right)$, $\mathrm{CCR}^{+}{ }^{+} \mathrm{CD} 45 \mathrm{RA}^{+}$(naive), and CCR7-CD45RA ${ }^{+}\left(\mathrm{T}_{\mathrm{EMRA}}\right)$. The purity of the cell populations exceeded $97 \%$ in all experiments. On the same day, effector cells were added to the infected and ${ }^{51} \mathrm{Cr}$-pulsed monocytes at the indicated effector/target ratios for 4 hours. Supernatants were collected, and target cell lysis was calculated by quantifying ${ }^{51} \mathrm{Cr}$ release. The spontaneous release of ${ }^{51} \mathrm{Cr}$ in the absence of $\mathrm{T}$ cells was less than $10 \%$. Results were expressed as percent specific lysis, calculated as follows: (experimental release - spontaneous release)/(maximum release - spontaneous release).

Quantification of mycobacterial growth. To measure mycobacterial growth, cells were lysed with $0.3 \%$ saponin (Sigma-Aldrich) to release intracellular bacteria. At all time points, an aliquot of unlysed infected cells was harvested and counted. This allowed exact quantification of cells as well as determination of cellular viability by trypan blue exclusion. Recovery of cells was greater than $80 \%$ in all experiments, with cell viability regularly exceeding $90 \%$ of total cells. Lysates of infected cells were resuspended vigorously, transferred into screw-cap tubes, and sonicated in a preheated water bath sonicator for 5 minutes at $37^{\circ} \mathrm{C}$.

Patients. Patients were recruited from 2002 to 2008 in the outpatient departments of the Institute for Clinical Immunology at the University Clinic of Erlangen and the Medical Clinic III of the University Clinic in Ulm. Patients included in the study fulfilled the criteria of the American College of Rheumatology for diagnosis of RA (84) or the modified New York criteria for diagnosis of AS (85). All had at least 1 unsuccessful course of treatment with a disease-modifying antirheumatic drug and evidence of erosive disease on radiographs of hand or feet. Patients were treated with infliximab (3-5 mg/kg body weight; weeks 0 and 2). No other changes in therapy of the patient's disease were required concurrent with initiation of infliximab therapy. Previous exposure to mycobacterial antigen was determined by intradermal injection of tuberculin (GT1; Chiron Behring) and measurement of the induration 3 to 5 days later. Depending on disease severity, some patients received methotrexate and or glucocorticoids in addition to infliximab. Table 1 summarizes the demographic and clinical data of the study population. The study was approved by the ethical commission of the University of Erlangen, and written informed consent was obtained from all patients and donors before they entered the study.

Biotinylation and detection of infliximab. We incubated $100 \mu \mathrm{l}$ biotin of a $10-\mathrm{mM}$ stock and $10 \mathrm{mg} / \mathrm{ml}$ infliximab on ice for 2 hours. Unbound biotin was removed by dialysis (Spectra/Por Micro DispoDialyzer; Cole-Parmer) into $11 \mathrm{PBS}$ overnight at $4^{\circ} \mathrm{C}$. To detect membrane TNF, $5 \times 10^{5} \mathrm{PBMCs}$ were incubated with $10 \mu \mathrm{g} / \mathrm{ml}$ biotin-conjugated infliximab or mouse IgG1 for 20 minutes on ice. Cells were washed with ice-cold buffer (PBS plus 2\% FCS) and stained with $0.5 \mu \mathrm{l}$ allophycocyanin-conjugated streptavidin on ice.

Complement-mediated cytotoxicity. PBMCs $\left(5 \times 10^{5}\right)$ from healthy donors or autoimmune patients were seeded in $100 \mu \mathrm{l}$ complete medium. Biotin-conjugated infliximab $(10 \mu \mathrm{g} / \mathrm{ml})$ or mouse IgG1 were added and incubated on ice for 20 minutes. Allophycocyanin-conjugated streptavidin $(0.5 \mu \mathrm{l})$ was added for 20 minutes on ice. Cells were incubated with rabbit-complement (25\%) on ice for 60 minutes, then washed twice in PBS plus $2 \%$ FCS. PerCPconjugated anti-CD8 (1 $\mu \mathrm{l})$ or PE-conjugated anti-CD56 (3 $\mu \mathrm{l})$ was added, and stained cells were immediately analyzed by flow cytometry.

$I F N-\gamma$ ELISA. Supernatants were harvested and filtered through a $0.2-\mu \mathrm{m}$ syringe. Filtered supernatants were plated on $7 \mathrm{H} 9$ agar plates and cultured for 2 weeks to confirm sterility. Samples were stored at $-70^{\circ} \mathrm{C}$ until being tested in a commercially available IFN- $\gamma$ sandwich ELISA (Endogen).

Statistics. Data are presented as mean \pm SEM unless otherwise indicated. A 2-tailed Student's $t$ test was used to determine statistical significance between 2 differentially treated cultures. A $P$ value less than 0.05 was considered significant.

\section{Acknowledgments}

This work was supported by the BMBF program for Infectious Disease Research ("Comprehensive Infectious Disease Center Ulm"), the Interdisciplinary Center for Clinical Research (IZKF, Erlangen, Germany), and the European Union (TB-VAC). The expert assistance of Kiki Castiglione, Nina Schwerdtner, and Bettina Radatz is greatly appreciated. We are grateful to our clinical collaborators Mathias Grünke, Bernhard Manger, and Beate Grüner. We appreciate the continuous advice of Martin Röllinghoff and Jochen R. Kalden throughout the study.

Received for publication January 5, 2009, and accepted in revised form March 25, 2009.

Address correspondence to: Steffen Stenger, Universitätsklinikum Ulm, Institut für Medizinische Mikrobiologie und Hygiene, Albert Einstein Allee 11, 89081 Ulm, Germany. Phone: 49-500-65300; Fax: 49-500-65302; E-mail: steffen.stenger@uniklinik-ulm.de.
1. Wolfe, F., Michaud, K., Anderson, J., and Urbansky, K. 2004. Tuberculosis infection in patients with rheumatoid arthritis and the effect of infliximab therapy. Arthritis Rheum. 50:372-379.

2. Elliott, M.J., et al. 1994. Randomised double-blind comparison of chimeric monoclonal antibody to tumour necrosis factor alpha (cA2) versus placebo in rheumatoid arthritis. Lancet. 344:1105-1110.

3. Maini, R., et al. 1999. Infliximab (chimeric antitumour necrosis factor alpha monoclonal antibody) versus placebo in rheumatoid arthritis patients receiving concomitant methotrexate: a randomised phase III trial. ATTRACT Study Group. Lancet. 354:1932-1939.

4. Feldmann, M., and Maini, S.R. 2008. Role of cytokines in rheumatoid arthritis: an education in pathophysiology and therapeutics. Immunol. Rev. 223:7-19.

5. Scott, D.L., and Kingsley, G.H. 2006. Tumor necrosis factor inhibitors for rheumatoid arthritis. N. Engl. J. Med. 355:704-712.

6. Lin, P.L., Plessner, H.L., Voitenok, N.N., and Flynn, J.L. 2007. Tumor necrosis factor and tuberculosis. J. Investig. Dermatol. Symp. Proc. 12:22-25.
7. Flynn, J.L., et al. 1995. Tumor necrosis factor-alpha is required in the protective immune response against Mycobacterium tuberculosis in mice. Immunity. 2:561-572.

8. Adams, L.B., et al. 1995. Exacerbation of acute and chronic murine tuberculosis by administration of a tumor necrosis factor receptor-expressing adenovirus. J. Infect. Dis. 171:400-405.

9. Bean, A.G., et al. 1999. Structural deficiencies in granuloma formation in TNF gene-targeted mice underlie the heightened susceptibility to aerosol Mycobacterium tuberculosis infection, which is 
not compensated for by lymphotoxin. J. Immunol. 162:3504-3511.

10. Mohan, V.P., et al. 2001. Effects of tumor necrosis factor alpha on host immune response in chronic persistent tuberculosis: possible role for limiting pathology. Infect. Immun. 69:1847-1855.

11. Botha, T., and Ryffel, B. 2003. Reactivation of latent tuberculosis infection in TNF-deficient mice. J. Immunol. 171:3110-3118.

12. Byrd, T.F. 1997. Tumor necrosis factor alpha (TNFalpha) promotes growth of virulent Mycobacterium tuberculosis in human monocytes ironmediated growth suppression is correlated with decreased release of TNFalpha from iron-treated infected monocytes. J. Clin. Invest. 99:2518-2529.

13. Buettner, M., et al. 2005. Inverse correlation of maturity and antibacterial activity in human dendritic cells. J. Immunol. 174:4203-4209.

14. Engele, M., et al. 2002. Induction of TNF in human alveolar macrophages as a potential evasion mechanism of virulent Mycobacterium tuberculosis. J. Immunol. 168:1328-1337.

15. Thoma-Uszynski, S., et al. 2001. Induction of direct antimicrobial activity through mammalian toll-like receptors. Science. 291:1544-1547.

16. Keane, J., et al. 2001. Tuberculosis associated with infliximab, a tumor necrosis factor alpha- neutralizing agent. N. Engl. J. Med. 345:1098-1104.

17. Gomez-Reino, J.J., Carmona, L., Valverde, V.R., Mola, E.M., and Montero, M.D. 2003. Treatment of rheumatoid arthritis with tumor necrosis factor inhibitors may predispose to significant increase in tuberculosis risk: a multicenter active-surveillance report. Arthritis Rheum. 48:2122-2127.

18. Ottenhoff, T.H., Ab, B.K., Van Embden, J.D., Thole, J.E., and Kiessling, R. 1988. The recombinant $65-\mathrm{kD}$ heat shock protein of Mycobacterium bovis Bacillus Calmette-Guerin/M. tuberculosis is a target molecule for CD4+ cytotoxic T lymphocytes that lyse human monocytes. J. Exp. Med. 168:1947-1952.

19. Bastian, M., Braun, T., Bruns, H., Rollinghoff, M., and Stenger, S. 2008. Mycobacterial lipopeptides elicit CD4+ CTLs in mycobacterium tuberculosisinfected humans. J. Immunol. 180:3436-3446.

20. van de Berg, P.J., van Leeuwen, E.M., ten Berge, I.J., and van Lier, R. 2008. Cytotoxic human CD4(+) T cells. Curr. Opin. Immunol. 20:339-343.

21. Woodworth, J.S., and Behar, S.M. 2006. Mycobacterium tuberculosis-specific CD8+ T cells and their role in immunity. Crit. Rev. Immunol. 26:317-352.

22. Stenger, S., et al. 1998. An antimicrobial activity of cytolytic T cells mediated by granulysin. Science. 282:121-125

23. Stegelmann, F., et al. 2005. Coordinate expression of CC chemokine ligand 5 , granulysin, and perforin in CD8 + T cells provides a host defense mechanism against Mycobacterium tuberculosis. J. Immunol. 175:7474-7483.

24. Clayberger, C., and Krensky, A.M. 2003. Granulysin. Curr. Opin. Immunol 15:560-565.

25. Pena, S.V., and Krensky, A.M. 1997. Granulysin, a new human cytolytic granule-associated protein with possible involvement in cell-mediated cytotoxicity. Semin. Immunol. 9:117-125.

26. Ochoa, M.T., et al. 2001. T-cell release of granulysin contributes to host defense in leprosy. Nat. Med. 7:174-179.

27. Rosat, J.P., et al. 1999. CD1-restricted microbial lipid antigen-specific recognition found in the CD8+ alpha beta T cell pool. J. Immunol. 162:366-371.

28. Gansert, J.L., et al. 2003. Human NKT cells express granulysin and exhibit antimycobacterial activity. J. Immunol. 170:3154-3161.

29. Dieli, F., et al. 2000. Vgamma9/Vdelta2 T lymphocytes reduce the viability of intracellular Mycobacterium tuberculosis. Eur. J. Immunol. 30:1512-1519.

30. Pena, S.V., Hanson, D.A., Carr, B.A., Goralski, T.J., and Krensky, A.M. 1997. Processing, subcellular localization, and function of 519 (granulysin), a human late $\mathrm{T}$ cell activation molecule with homology to small, lytic, granule proteins. J. Immunol. 158:2680-2688.

31. Deng, A., et al. 2005. Granulysin, a cytolytic molecule, is also a chemoattractant and proinflammatory activator. J. Immunol. 174:5243-5248.

32. Huang, L.P., Lyu, S.C., Clayberger, C., and Krensky, A.M. 2007. Granulysin-mediated tumor rejection in transgenic mice. J. Immunol. 178:77-84.

33. Ma, L.L., et al. 2002. CD8 T cell-mediated killing of Cryptococcus neoformans requires granulysin and is dependent on CD4 T cells and IL-15. J. Immunol. 169:5787-5795.

34. da Silva, A.P., et al. 2008. In vitro and in vivo antimicrobial activity of granulysin-derived peptides against Vibrio cholerae. J. Antimicrob. Chemother. 61:1103-1109.

35. McInturff, J.E., et al. 2005. Granulysin-derived peptides demonstrate antimicrobial and anti-inflammatory effects against Propionibacterium acnes. J. Invest. Dermatol. 125:256-263.

36. Farouk, S.E., Mincheva-Nilsson, L., Krensky, A.M. Dieli, F., and Troye-Blomberg, M. 2004. Gamma delta $\mathrm{T}$ cells inhibit in vitro growth of the asexual blood stages of Plasmodium falciparum by a granule exocytosis-dependent cytotoxic pathway that requires granulysin. Eur. J. Immunol. 34:2248-2256.

37. Hamann, D., et al. 1997. Phenotypic and functional separation of memory and effector human CD8+ T cells. J. Exp. Med. 186:1407-1418.

38. Sallusto, F., Lenig, D., Forster, R., Lipp, M., and Lanzavecchia, A. 1999. Two subsets of memory T lymphocytes with distinct homing potentials and effector functions. Nature. 401:708-712.

39. Geginat, J., Lanzavecchia, A., and Sallusto, F. 2003. Proliferation and differentiation potential of human CD8+ memory T-cell subsets in response to antigen or homeostatic cytokines. Blood. 101:4260-4266.

40. Wallis, R.S., Broder, M.S., Wong, J.Y., Hanson, M.E., and Beenhouwer, D.O. 2004. Granulomatous infectious diseases associated with tumor necrosis factor antagonists. Clin. Infect. Dis. 38:1261-1265.

41. Orme, I.M., and Collins, F.M. 1984. Adoptive protection of the Mycobacterium tuberculosis-infected lung. Dissociation between cells that passively transfer protective immunity and those that transfer delayed-type hypersensitivity to tuberculin. Cell. Immunol. 84:113-120.

42. Orme, I.M. 1987. The kinetics of emergence and loss of mediator $\mathrm{T}$ lymphocytes acquired in response to infection with Mycobacterium tuberculosis. J. Immunol. 138:293-298.

43. Muller, I., Cobbold, S.P., Waldmann, H., and Kaufmann, S.H. 1987. Impaired resistance to Mycobacterium tuberculosis infection after selective in vivo depletion of L3T4+ and Lyt-2+ T cells. Infect. Immun. 55:2037-2041.

44. Flynn, J.L., Goldstein, M.M., Triebold, K.J., Koller, B., and Bloom, B.R. 1992. Major histocompatibility complex class I-restricted $\mathrm{T}$ cells are required for resistance to Mycobacterium tuberculosis infection. Proc. Natl. Acad. Sci. U. S. A. 89:12013-12017.

45. Turner, J., and Dockrell, H.M. 1996. Stimulation of human peripheral blood mononuclear cells with live Mycobacterium bovis BCG activates cytolytic CD8+ T cells in vitro. Immunology. 87:339-342.

46. Tan, J.S., et al. 1997. Human alveolar T lymphocyte responses to Mycobacterium tuberculosis antigens: role for CD4+ and CD8+ cytotoxic T cells and relative resistance of alveolar macrophages to lysis. J. Immunol. 159:290-297.

47. Stenger, S., et al. 1997. Differential effects of cytolytic T cell subsets on intracellular infection. Science. 276:1684-1687.

48. Ernst, W.A., et al. 2000. Granulysin, a T cell product, kills bacteria by altering membrane permeability. J. Immunol. 165:7102-7108.
49. Sahiratmadja, E., et al. 2007. Plasma granulysin levels and cellular interferon-gamma production correlate with curative host responses in tuberculosis, while plasma interferon-gamma levels correlate with tuberculosis disease activity in adults. Tuberculosis (Edinb.). 87:312-321.

50. Dieli, F., et al. 2002. Selective depression of interferon-gamma and granulysin production with increase of proliferative response by Vgamma9/ Vdelta2 $\mathrm{T}$ cells in children with tuberculosis. J. Infect. Dis. 186:1835-1839.

51. Di Liberto, D., et al. 2007. Decreased serum granulysin levels in childhood tuberculosis which reverse after therapy. Tuberculosis (Edinb.). 87:322-328.

52. Chung, W.H., et al. 2008. Granulysin is a key mediator for disseminated keratinocyte death in StevensJohnson syndrome and toxic epidermal necrolysis. Nat. Med. 14:1343-1350.

53. Champagne, P., et al. 2001. Skewed maturation of memory HIV-specific CD8 T lymphocytes. Nature. 410:106-111.

54. [No authors listed]. 2000. Targeted tuberculin testing and treatment of latent tuberculosis infection. This official statement of the American Thoracic Society was adopted by the ATS Board of Directors, July 1999. This is a Joint Statement of the American Thoracic Society (ATS) and the Centers for Disease Control and Prevention (CDC). This statement was endorsed by the Council of the Infectious Diseases Society of America. (IDSA), September 1999, and the sections of this statement. Am. J. Respir. Crit. Care Med. 161:S221-S247.

55. Hess, C., et al. 2004. HIV-1 specific CD8+ T cells with an effector phenotype and control of viral replication. Lancet. 363:863-866.

56. Northfield, J.W., et al. 2007. Human immunodeficiency virus type 1 (HIV-1)-specific CD8+ T(EMRA) cells in early infection are linked to control of HIV-1 viremia and predict the subsequent viral load set point. J. Virol. 81:5759-5765.

57. Faint, J.M., et al. 2001. Memory T cells constitute a subset of the human CD8+CD45RA+ pool with distinct phenotypic and migratory characteristics. J. Immunol. 167:212-220.

58. Hohn, H., et al. 2003. Definition of the HLA-A2 restricted peptides recognized by human $\mathrm{CD} 8+$ effector $\mathrm{T}$ cells by flow-assisted sorting of the CD8+ CD45RA+. Clin. Exp. Immunol. 131:102-110.

59. Caccamo, N., et al. 2006. Phenotypical and functional analysis of memory and effector human CD8 T cells specific for mycobacterial antigens. J. Immunol. 177:1780-1785.

60. Jacobsen, M., et al. 2007. Clonal expansion of CD8+ effector T cells in childhood tuberculosis. J. Immunol. 179:1331-1339.

61. Maurice, M.M., et al. 1999. Treatment with monoclonal anti-tumor necrosis factor alpha antibody results in an accumulation of Th1 CD4+ T cells in the peripheral blood of patients with rheumatoid arthritis. Arthritis Rheum. 42:2166-2173.

62. Barnes, P.F., et al. 1993. Cytokine production at the site of disease in human tuberculosis. Infect. Immun. 61:3482-3489.

63. McShane, H., Behboudi, S., Goonetilleke, N., Brookes, R., and Hill, A.V. 2002. Protective immunity against Mycobacterium tuberculosis induced by dendritic cells pulsed with both $\mathrm{CD} 8(+)$ - and CD4(+)-T-cell epitopes from antigen 85A. Infect. Immun. 70:1623-1626.

64. Sallusto, F., Geginat, J., and Lanzavecchia, A. 2004. Central memory and effector memory $T$ cell subsets: function, generation, and maintenance. Annu. Rev. Immunol. 22:745-763.

65. Taylor, P.C., et al. 2000. Reduction of chemokine levels and leukocyte traffic to joints by tumor necrosis factor alpha blockade in patients with rheumatoid arthritis. Arthritis Rheum. 43:38-47.

66. Tak, P.P., et al. 1996. Decrease in cellularity and 
expression of adhesion molecules by anti-tumor necrosis factor alpha monoclonal antibody treatment in patients with rheumatoid arthritis. Arthritis Rheum. 39:1077-1081.

67. Newton, S.M., et al. 2008. Reduction of chemokine secretion in response to mycobacteria in infliximabtreated patients. Clin. Vaccine Immunol. 15:506-512.

68. Bueno, C., et al. 2002. A new method for detecting TNF-alpha-secreting cells using directimmunofluorescence surface membrane stainings. J. Immunol. Methods. 264:77-87.

69. Dinarello, C.A. 2005. Differences between antitumor necrosis factor-alpha monoclonal antibodies and soluble TNF receptors in host defense impairment. J. Rheumatol. Suppl. 74:40-47.

70. Scallon, B., et al. 2002.Binding and functional comparisons of two types of tumor necrosis factor antagonists. J. Pharmacol. Exp. Ther. 301:418-426.

71. Mitoma, H., et al. 2008. Mechanisms for cytotoxic effects of anti-tumor necrosis factor agents on transmembrane tumor necrosis factor alpha-expressing cells: comparison among infliximab, etanercept, and adalimumab. Arthritis Rheum. 58:1248-1257.

72. Hamdi, H., et al. 2006. Inhibition of anti-tuberculosis T-lymphocyte function with tumour necrosis factor antagonists. Arthritis Res. Ther. 8:R114.

73. Appel, H., et al. 2007. In vitro observations of $\mathrm{T}$ cell responsiveness to recall antigens during tumor necrosis factor-alpha-blocking therapy in patients with ankylosing spondylitis. J. Rheumatol. 34:2264-2270.

74. Griffiths, G.M., Alpert, S., Lambert, E., McGuire, J., and Weissman, I.L. 1992. Perforin and granzyme A expression identifying cytolytic lymphocytes in rheumatoid arthritis. Proc. Natl. Acad. Sci. U. S. A. 89:549-553.

75. Gulan, G., et al. 2003. Systemic and local expression of perforin in lymphocyte subsets in acute and chronic rheumatoid arthritis. J. Rheumatol. 30:660-670.

76. Lorenz, H.M., et al. 1996. In vivo blockade of TNFalpha by intravenous infusion of a chimeric monoclonal TNF-alpha antibody in patients with rheumatoid arthritis. Short term cellular and molecular effects. J. Immunol. 156:1646-1653.

77. Charles, P., et al. 1999. Regulation of cytokines, cytokine inhibitors, and acute-phase proteins following anti-TNF-alpha therapy in rheumatoid arthritis. J. Immunol. 163:1521-1528.

78. Ohshima, S., et al. 1999. Long-term follow-up of the changes in circulating cytokines, soluble cytokine receptors, and white blood cell subset counts in patients with rheumatoid arthritis (RA) after monoclonal anti-TNF alpha antibody therapy. J. Clin. Immunol. 19:305-313.

79. Lorenz, H.M., et al. 2000. In vivo blockade of tumor necrosis factor-alpha in patients with rheumatoid arthritis: longterm effects after repeated infusion of chimeric monoclonal antibody cA2. J. Rheumatol. 27:304-310.

80. Cornillie, F., et al. 2001. Infliximab induces potent anti-inflammatory and local immunomodulatory activity but no systemic immune suppression in patients with Crohn's disease. Aliment Pharmacol. Ther. 15:463-473.

81. Zou, J., et al. 2003. Down-regulation of the nonspecific and antigen-specific $\mathrm{T}$ cell cytokine response in ankylosing spondylitis during treatment with infliximab. Arthritis Rheum. 48:780-790.

82. Baeten, D., et al. 2001. Impaired Th1 cytokine production in spondyloarthropathy is restored by antiTNFalpha. Ann. Rheum. Dis. 60:750-755.

83. Ehrenstein, M.R., et al. 2004. Compromised function of regulatory $\mathrm{T}$ cells in rheumatoid arthritis and reversal by anti-TNFalpha therapy. J. Exp. Med. 200:277-285.

84. Arnett, F.C., et al. 1988. The American Rheumatism Association 1987 revised criteria for the classification of rheumatoid arthritis. Arthritis Rheum. 31:315-324.

85. van der Linden, S., Valkenburg, H.A., and Cats, A. 1984. Evaluation of diagnostic criteria for ankylosing spondylitis. A proposal for modification of the New York criteria. Arthritis Rheum. 27:361-368. 